\section{WAINWRIGHT RECONSIDERED: PRISONS, FAMILIES AND THE HUMAN RIGHTS ACT}

Questions of the legal rights of prisoners continue to occupy the courts, and there is increased judicial consideration of questions of the rights of prisoners' partners and children. Prisoners' family members occupy an uncertain legal position: they are technically free but their family lives are underpinned by the decisions of prison governors and the courts. The case of Wainwright $v$ Home Office [2003] UKHL 53 illustrates the inadequacy of existing legal categories for dealing with questions of rights and dignity in relation to prisoners' families. This case relates to conduct which took place before the Human Rights Act 1998 came into force: it is tempting to speculate whether cases such as this will be decided differently in the future under the aegis of the HRA (see Lester, M (2004) "Wainwright v Home Office, Case Comment", EHRLR, vol. 2, pp193-99; Morgan, J (2004) "Privacy Torts: Out with the Old, Out with the New", Law Quarterly Review, vol 120, pp 393-98).

Mrs Wainwright, and her disabled son, Alan, went to visit Alan's half-brother who was a remand prisoner. The prison authorities suspected the prisoner of dealing drugs, so required his visitors to be strip-searched. The searches were governed by the prison's internal code of practice. Alan alleged that the person who searched him had touched his penis and lifted his foreskin. Mrs. Wainwright believed that she could be seen by people in the block opposite, since it was dark outside and the blinds were not closed: she was stripped naked with her knickers around her ankles and her vest above her breasts (see Lester, op cit). They were not asked to sign consent forms until afterwards and were told that if they did not consent they might not be allowed to visit. Nothing was found during the searches. Mrs Wainwright complained of the infliction of emotional distress; Alan claimed to have suffered post-traumatic stress disorder. Alan was awarded damages at first instance for the trespass to the person (see Codd, H (2005) “Integrating Empirical Research: Prisoners' Rights, the Law and the Family", IALS, WG Hart Legal Workshop, June 2005).

The Wainwrights' ultimate appeal to the House of Lords was dismissed on the grounds that any tort based on the case of Wilkinson v Downton [1897] QB 57 required actual intention or recklessness as to the causing of harm whereas the officers' conduct amounted to mere "sloppiness". Second, the Lords rejected arguments for the existence of a general tort of the invasion of privacy. Third, Hoffman LJ rejected arguments that if the English courts did not create a tort of invasion of privacy then the ECHR would find a violation of Articles 3 and 8 (See Foster, S (2005) "Prison Conditions, Human Rights and Article 3 ECHR", Public Law, spring, pp 35-44). Following the precedent from Malone v Metropolitan Police Commissioner [1979] Ch 344 it

Articles
No loss - or is there? The awkward case of the
trustee's claim for damages
Reforming the public sector in the EU: the
new public procurement regime
Society News
$\begin{aligned} & \text { Articles (contd) } \\ & \text { To transform the international criminal trial: } \\ & \text { merging restorative and retributive justice } \\ & \text { Dual board system under German law }\end{aligned}$

was not enough for Mrs Wainwright to argue that the searches were conducted without statutory authority. With the exception of the actual battery to Alan, for which he was awarded damages, there had been no tortious conduct, and thus no liability.

Both Hoffman LJ and Scott LJ seemed to view distress as "a trivial kind of harm". Although described as "a glaring example of degrading behaviour by a public authority" Scott LJ agreed with Lord Hoffman that the conduct was not tortious, and compared the facts to the humiliating initiation ceremonies held by some groups and institutions in which, he argued, it was not appropriate for the law of tort to intervene. This is shocking to the reader familiar with the literature on the experiences of prisoners' families, for whom visits are a source of profound stress even in the absence of strip-searches. The law of privacy seems ill-fitted to respond to the experiences of the Wainwrights, but at the time there was no other legal avenue open to them. It has been suggested that, now the HRA is in force, Article 8 considerations may be more important in future cases. However, Wainwright illustrates the problems of seeking redress through the courts for the negative experiences of prisoners' families, and reflects a robust rather than empathetic understanding of these issues. It remains to be seen whether the Human Rights Act means that, in future, such cases will be decided differently.

\section{Helen Codd}

Principal Lecturer in Law, Lancashire Law School, University of Central Lancashire; Associate Research Fellow, IALS

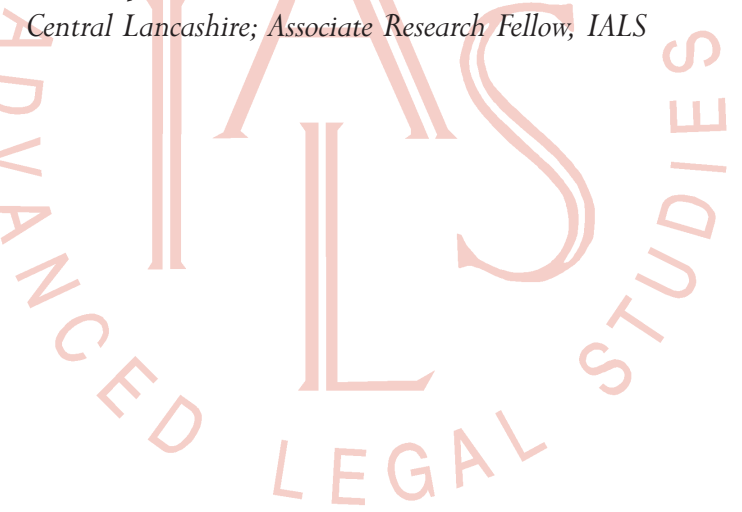

